\title{
Occult Hepatitis B Virus Infection Among Hemodialysis Patients in Fakous General Hospital
}

\author{
Asmaa Sobhy Mohamed, Nermien Raaft abdel Fattah, Waleed Abdulfattah Ismail, Emad Abdel-Latif \\ Department of Internal Medicine, Faculty of Medicine, Zagazig University, Sharkia, Egypt \\ * Corresponding author: Asmaa Sobhy Mohamed, Mobile: (+20)01067194692 Email: asmaasobhy@gmail.com
}

\begin{abstract}
Background: Occult HBV infection (OBI) is defined as the presence of a small amount of $\mathrm{HBV}$ in patients with negative serum for hepatitis B surface antigen (HBs Ag). The serum HBV DNA level in these patients is generally lower than 104 copies $/ \mathrm{mL}$, there is a high prevalence of OBI in patients with chronic hepatitis C, HCC cryptogenic liver disease, and HIV. Objectives: Assessment of prevalence of Occult Hepatitis B Virus infection among hemodialysis patients in Fakous General Hospital.

Patients and Methods: A total of 40 patients with end-stage renal disease undergoing regular HD (for at least 6 months underwent a complete physical examination. Serum samples were collected between before hemodialysis and then stored at $-80 \mathrm{C}^{\circ}$ until tested. Serological markers of $\mathrm{HBV}$ infection (HBsAg, anti-HBs, anti-HBc) were determined using standard third generation commercially available enzyme immunoassays).

Results: The 40 patients who have been included in this study had a minimum age of 25 years and a maximum age of 78 years. The number of females was 25 with a percentage of $62.5 \%$ and the percentage of males was about $37.5 \%$ (15 males). 22 patients (55\%) had negative sera for anti-HCV antibody and a percentage of $37 \%$ and $63 \%$ for the distribution of females and males, respectively. 18 patients $(45 \%)$ had positive sera for anti-HCV antibody and $37 \%$ of them were females and $63 \%$ of them were males.
\end{abstract}

Conclusions: OBI infection is a relatively common infection (37.5\%) among chronic hemodialysis patients in the dialysis unit of Fakous general hospital.

Keywords: Occult Hepatitis B Virus Infection, Haemodialysis Patients, Fakous General Hospital.

\section{INTRODUCTION}

The hepatitis B virus (HBV) is a well-known blood-borne virus because it is transmitted through exposure to infective blood, semen, and other body fluids, peripheral blood mononuclear cells (PBMCs), and sharing needles ${ }^{(\mathbf{1})}$.

Acute HBV can be a self-limiting or it can be a chronic infection and increases the risk of developing liver failure, hepatocellular carcinoma (HCC), or cirrhosis ${ }^{(2)}$. Occult hepatitis B infection (OHBI) is a new clinical form of hepatitis $B$ that is characterized by the presence of HBV DNA in the liver with detectable $(<200 \mathrm{UI} / \mathrm{mL})$ or undetectable HBV DNA in the serum in HBsAg negative patients and can be classified into seropositive (anti-HBc and/or anti-HBs positive) and seronegative (absence of anti-HBc and anti-HBs) ${ }^{(3)}$.

The prevalence of OHBI varies from $1 \%$ to $87 \%$ in different regions of the world. The frequency of OHBI in patients with liver cirrhosis and cryptogenic chronic liver ranged from $2.7 \%$ to $60 \%$ and $1.9 \%$ to $55.6 \%$ respectively ${ }^{(4)}$.

Patients with chronic renal failure (CRF) on hemodialysis are at higher risk for acquiring Hepatitis B Virus ${ }^{(5)}$.

HD patients, compared to patients without renal failure are more to become chronic HBV carriers ${ }^{(6)}$.

This study aimed to investigate the prevalence of OBI in HD patients. We used a highly sensitive and specific PCR method to test for OBI and we determined the prevalence of anti-HBc and HBV DNA in the HD patients with undetectable $\mathrm{HBs} \mathrm{Ag}$.

We also correlated the clinical, epidemiologic, and laboratory test characteristics of patients with OBI and with or without $\mathrm{HCV}$ co-infection.

\section{SUBJECTS AND METHODS}

This comparative cross-sectional study included 40 patients of ESRD on long-term hemodialysis in the dialysis unit of Fakous Hospital after they agreed to screen the prevalence of occult hepatitis B virus among them and to study its possible effects.

\section{Inclusion criteria:}

This study aimed to include all patients, who are known to have an end-stage renal disease on long-term hemodialysis in the dialysis unit of Fakous Hospital if they agree and do not have any of the exclusion criteria. Patients have different ages, genders, occupations, pasthistory of blood transfusions, past-history of previous surgeries, and durations on hemodialysis. They live in Fakous city or the rural areas around it. Patients also have different causes of end-stage renal disease and have different co-morbidities as diabetes, hypertension, or both.

The 40 patients were all candidate for the following after written agreement signed by them: 
* Proper history taking including name, age, sex, occupation, history of blood transfusion, liver disease, and duration of hemodialysis was obtained.

* Full clinical assessment for relevant clinical signs.

* Screening for anti-HCV antibody as a marker for HCV infection and $\mathrm{HBsAg}$ as a marker for $\mathrm{HBV}$ as a confirmation for previous virology results recorded in patients' files.

* Liver function tests (serum transaminases, serum albumin, and serum total bilirubin).

* Complete blood picture (hemoglobin, white blood cells, and platelets).

* Screening for occult HBV infection by; Screening for anti-HBC by ELISA. Screening for HBV-DNA by realtime polymerase chain reaction (PCR).

Pelvic abdominal US.

Site of the study; Medical biochemistry department and Zagazig scientific medicine research center in Zagazig university.

\section{Specimen collection and preparation:}

Five $\mathrm{ml}$ of blood were collected in a clean test tube without any anticoagulant using an aseptic technique. Each specimen was spun down, within one hour of its collection, at 3000 rounds per minute (r.p.m) for 10 minutes. The serum was divided into two aliquots, one of them was sent to the laboratory for liver function tests and the other was stored at $-20^{\circ}$ till it was tested for serology (anti-HCV) and detection of HBVDNA by RT-PCR. Another $2 \mathrm{ml}$ of blood was collected in a purple tube containing EDTA as an anticoagulant and was sent to the lab within 24 hours to be examined for a complete blood count.

\section{Enzyme-linked immunoassay test:}

The presence of anti-HBc and $\mathrm{HBs} \mathrm{Ag}$ were determined by Enzyme-Linked Immuno Assay test kit (Diapro, Milano, Italy) according to the manufacturer's instruction. Patients who were positive for total anti$\mathrm{HBc}$ and negative for $\mathrm{HBs} \mathrm{Ag}$ were investigated for HBV DNA.

\section{REAL-TIME PCR:}

Viral DNA was extracted from $200 \mu \mathrm{l}$ serum with QIAamp DNA blood mini kit (Qiagen, Cat. No. 51104Germany) through the following steps; $200 \mu \mathrm{l}$ of buffer AL "lysis buffer" was added to $200 \mu 1$ of serum in Eppendorf tube. The combination in the Eppendorf tube was mixed by a vortex. Eppendorf tube was heated to 60 ${ }^{\circ} \mathrm{C}$ for 10 minutes in the heat block then it was put in the centrifuge machine at 1000 r.p.m for 1 minute. 200 $\mu \mathrm{l}$ of ethanol was added to the Eppendorf tube content then it all was well mixed by the vortex.

The $600 \mu \mathrm{l}$ of the aforementioned mixture was transferred to QIAamp mini spin column. Each mixture was spun down at 8000 r.p.m for 1 minute. The separated below fluid in the collection tube was thrown. $500 \mu \mathrm{l}$ of AW-1 was added to the QIAamp Mini spin column content. The mixture was spun down at
6000 r.p.m for 1 minute. The collection tube with the separated fluid in it was thrown. The QIAamp mini spin column was added to the new collection tube. $500 \mu \mathrm{l}$ of AW-2 was added to the QIAamp Mini spin column content. The mixture was spun down at 14000 r.p.m for 3 minutes.

The collection tube with the separated fluid in it was thrown. The mixture was spun down at 14000 r.p.m for 3 minutes again and the collection tube with the separated fluid in it was thrown. The QIAamp mini spin column was added to a new Eppendorf tube. $200 \mu \mathrm{l}$ of AE buffer "Illusion buffer" was added to the content of the QIAamp mini spin column then the mixture was spun down at 12000 r.p.m for 3 minutes. The QIAamp mini spin column was thrown and the separated fluid in the Eppendorf tube was stored at $-20{ }^{\circ} \mathrm{C}$ for the next step.

\section{Real-time PCR for detection of OBI:}

We pipetted $20 \mu \mathrm{l}$ Protease $\mathrm{K}$ into, $20 \mathrm{ul}$ Carrier RNA into $2 \mathrm{ml}$ Microcentrifuge Tube. We Added 200 $\mu \mathrm{l}$ plasma or serum to the tube, added $10 \mathrm{ul}$ Internal control. We Added $200 \mu \mathrm{l}$ Lysis Buffer to the tube, closed the lid, and mixed by pulse-vortexing for $15 \mathrm{~s}$. To ensure efficient lysis, the sample and Lysis Buffer must be mixed thoroughly to yield a homogeneous solution. The lysis Buffer contains internal control. Since lysis buffer has a high viscosity, we should be sure to add the correct volume of Lysis Buffer by pipetting carefully or by using a suitable pipet such as an Eppendorf multistep pipet or equivalent.

I did not add Protease $\mathrm{K}$ directly to Lysis Buffer. We Incubated at $56^{\circ} \mathrm{C}\left( \pm 1^{\circ} \mathrm{C}\right)$ for $15 \mathrm{~min}( \pm 1 \mathrm{~min})$. We Centrifuged the Lysis Tube for $\geq 5 \mathrm{~s}$ at full speed to remove drops from the inside of the lid. we Changed gloves and opened the Lysis Tube carefully. We Added $300 \mu \mathrm{l}$ ethanol (96-100\%) to the lysis tube, we closed the lid and mixed thoroughly by pulse-vortexing for $\geq 15$ $\mathrm{s}$. Incubate for $5 \mathrm{~min}( \pm 1 \mathrm{~min})$ at room temperature (15$25^{\circ} \mathrm{C}$ ). We Centrifuged the Lysis Tube for $\geq 5 \mathrm{~s}$ at full speed to remove drops from the inside of the lid. We Inserted the column into the collection tube. We Changed gloves and opened only one tube at a time. We Carefully applied lysate from step 7 into the Column without wetting the rim. We centrifuged the column at $10000 \mathrm{rpm}$ for $30 \mathrm{sec}$, we emptied the collection tube.

We Applied $500 \mu \mathrm{l}$ Wash Buffer 1 (AW1) to the column, we centrifuged the column at $10000 \mathrm{rpm}$ for 30 sec., we emptied the collection tube. We Applied 500 $\mu 1$ Wash Buffer 2 (AW2) to the column without wetting the rim. We avoided touching the column membrane with the pipet tip. we centrifuged the column at 10000 rpm for $30 \mathrm{sec}$., we emptied the collection tube.

To a new microcentrifuge tube (not provided) we placed the column after discarding the collection tube, we centrifuged the column at maximum speed for 5 minutes. We Placed the column in a clean Elution Tube (not provided), we Carefully opened the lid of the 
column, and applied $50 \mu 1$ Elution Buffer (pre-warmed to $56 \mathrm{C}$ ) to the center of the membrane. We closed the lid and was incubated at room temperature $\left(15-25^{\circ} \mathrm{C}\right)$ for $\geq 3 \mathrm{~min}$. we centrifuged at full speed (approximately $20,000 \times g$, or $14,000 \mathrm{rpm}$ ) for $1 \mathrm{~min}$ to elute the viral nucleic acids.

Ethical approval and written informed consent :

An approval of the study was obtained from Zagazig University academic and ethical committee. Every patient signed an informed written consent for acceptance of the operation.

\section{Statistical analysis}

Recorded data were analyzed using the statistical package for social sciences, version 20.0 (SPSS Inc., Chicago, Illinois, USA). Quantitative data were expressed as mean \pm standard deviation (SD). Qualitative data were expressed as frequency and percentage. Independentsamples t-test of significance was used when comparing two means. Chi-square $\left(\mathrm{x}^{2}\right)$ test of significance was used to compare proportions between two qualitative parameters.

The confidence interval was set to $95 \%$ and the margin of error accepted was set to $5 \%$. The p-value was considered significant as the following: P-value $<0.05$ was considered significant. P-value $<0.001$ was considered highly significant. P-value $>0.05$ was considered insignificant.

\section{RESULTS}

Table (1): Demographic data of the studied group

\begin{tabular}{|c|c|}
\hline Variable & $\begin{array}{c}\text { Hemodialysis patients } \\
\text { No. } 40 \\
100 \%\end{array}$ \\
\hline $\begin{array}{l}\text { Sex } \\
\text { Male } \\
\text { Female }\end{array}$ & $\begin{array}{l}24(60 \%) \\
16(40 \%)\end{array}$ \\
\hline $\begin{array}{l}\text { Age (year) } \\
\text { mean } \pm \text { SD }\end{array}$ & $51.13 \pm 11.28$ \\
\hline $\begin{array}{l}\text { Occupation } \\
\text { Farmer } \\
\text { Housewife } \\
\text { Seller } \\
\text { Employee } \\
\text { Plumber } \\
\text { Nurse }\end{array}$ & $\begin{aligned} 15 & (37.5 \%) \\
13 & (32.5 \%) \\
3 & (7.5 \%) \\
5 & (12.5 \%) \\
2 & (5 \%) \\
2 & (5 \%)\end{aligned}$ \\
\hline $\begin{array}{l}\text { Residence } \\
\text { Rural } \\
\text { Urban }\end{array}$ & $\begin{array}{ll}29 & (72.5 \%) \\
11 & (27.5 \%)\end{array}$ \\
\hline $\begin{array}{l}\text { Socio-economic state } \\
\text { Low } \\
\text { Moderate } \\
\text { high }\end{array}$ & $\begin{array}{c}27(67.5 \%) \\
11(27.5 \%) \\
2(5 \%)\end{array}$ \\
\hline $\begin{array}{l}\text { Education state } \\
\text { Educated } \\
\text { Non-educated }\end{array}$ & $\begin{array}{c}13(32.5 \%) \\
27 \quad(67.5 \%)\end{array}$ \\
\hline
\end{tabular}

This table shows that this study consisted of 40 patients undergoing hemodialysis with age ranging from 25 to 78 years, $(60 \%)$ of the studied group are males, $(37.5 \%)$ of them are farmers, $(72.5 \%)$ of them are from rural areas, $(97.5 \%)$ of them have good mental state, $(67.5 \%)$ of them are of low socio-economic state, and $(67.5 \%)$ are non-educated.

Table (2): Anti HBc, HBV PCR, HCV antibodies of the studied group:

\begin{tabular}{|l|c|}
\hline Variable & $\begin{array}{c}\text { Hemodialysis patients } \\
\text { No. } \mathbf{4 0} \\
\mathbf{1 0 0} \%\end{array}$ \\
\hline Anti HBc & \\
$+V E$ & $\mathbf{1 5}$ \\
$-V E$ & $\mathbf{3 7 . 5 \%}$ \\
& $\mathbf{2 5}$ \\
\hline HBV PCR & $\mathbf{6 2 . 5 \%}$ \\
$+V E$ & $\mathbf{1}$ \\
$-V E$ & $\mathbf{2 . 5 \%}$ \\
& $\mathbf{3 9}$ \\
\hline HCV Ab & $\mathbf{9 7 . 5 \%}$ \\
$+V E$ & $\mathbf{2 0}$ \\
$-V E$ & $\mathbf{5 0 \%}$ \\
& $\mathbf{2 0}$ \\
& $\mathbf{5 0 \%}$ \\
\hline
\end{tabular}

This table shows that $37 \%$ of hemodialysis patients have +ve anti-HBc, $2.5 \%$ of them have +ve HBV PCR, and 50\% of them have +ve HCV antibodies.

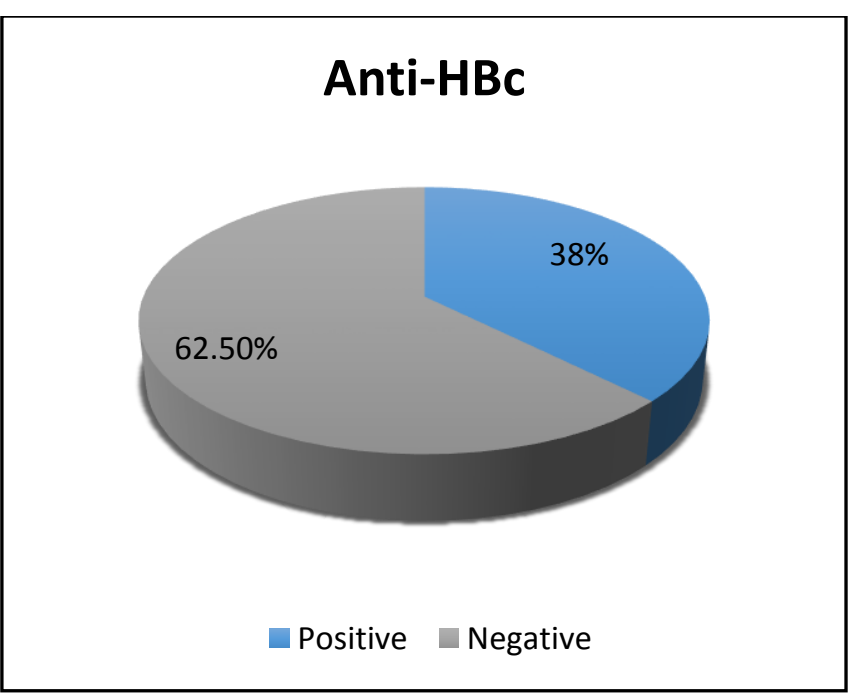

Fig (2): Pie chart for Anti HBc results of the studied group:

According to anti-HBc, hemodialysis patients are classified into two groups: Group (A): hemodialysis patients with positive anti-HBc. Group (B): hemodialysis patients with negative anti-HBc. 
Table (3): Comparison between group (A) and group (B) as regard HBV PCR and HCV antibodies:

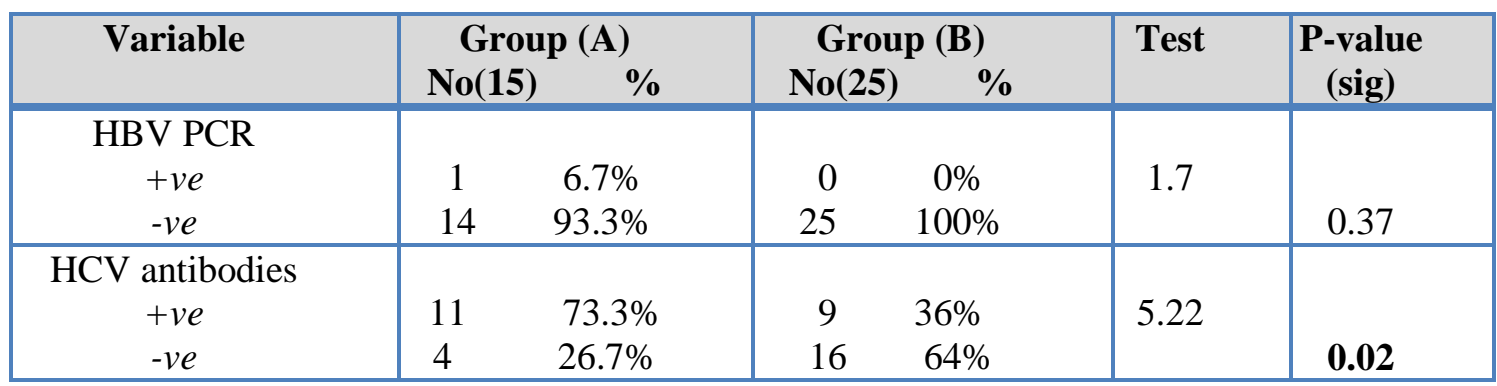

Chi-square test

This table shows that there are statistically significant differences between group (A) and group (B) as regard $\mathrm{HCV}$ antibodies which are more prevalent in group A.

Table (4): Comparison between group (A) and group (B) as regard duration of hemodialysis and transfusion units per month:

\begin{tabular}{|c|c|c|c|c|}
\hline Variable & $\begin{array}{c}\text { Group (A) } \\
\text { No. (15) }\end{array}$ & $\begin{array}{c}\text { Group (B) } \\
\text { No. (25) }\end{array}$ & Test & $\begin{array}{c}\text { P-value } \\
\text { (sig) }\end{array}$ \\
\hline $\begin{array}{c}\text { Duration of HD (year) } \\
\text { Mean } \pm \text { SD }\end{array}$ & $9.6 \pm 3.94$ & $4.66 \pm 1.99$ & 50.5 & $\mathbf{0 . 0 0 0}$ \\
\hline $\begin{array}{c}\text { Transfusion units / month } \\
\text { Mean } \pm \text { SD }\end{array}$ & $1.2 \pm 0.94$ & $1.36 \pm 0.75$ & 110.5 & $\mathbf{0 . 0 3}$ \\
\hline
\end{tabular}

Mann Whitney U test.

This table shows that there are statistically significant differences between group (A) and group (B) as regards the duration of hemodialysis and units of transfusion per month. Group A showed a highly significant long duration of dialysis and also more units of blood transfusion per month.

Table (5): Correlation between HBc and age, weight, SGOT, SGPT, HBV PCR, duration of dialysis, and units of blood transfusion per month.

\begin{tabular}{|c|c|c|c|}
\hline \multirow[t]{2}{*}{ Variable } & \multicolumn{3}{|c|}{ HBc } \\
\hline & $\mathbf{r}$ & $\mathbf{p}$ & SIG \\
\hline Age (year) & $-0.11 *$ & 0.48 & NS \\
\hline Weight (kg) & $-0.11 *$ & 0.46 & NS \\
\hline SGOT & $-0.08 \bullet$ & 0.60 & $\mathrm{NS}$ \\
\hline SGPT & $-0.08 \bullet$ & 0.62 & NS \\
\hline HBV PCR & $-0.27 \bullet$ & 0.08 & NS \\
\hline Duration of hemodialysis & $0.49 \bullet$ & 0.001 & $\mathbf{S}$ \\
\hline Units of transfusion/month & $0.08 \bullet$ & 0.5 & NS \\
\hline
\end{tabular}

This table shows that there is a statistically significant positive correlation between $\mathrm{HBc}$ level and duration of hemodialysis.

\section{DISCUSSION}

Factors that have been demonstrated to contribute to outbreaks of blood-borne infections e.g. hepatitis B virus (HBV) in some units are significant deficiencies in infection control practices and failure to give required vaccination to hemodialysis patients e.g. HBV vaccine. Additionally, the use of multi-dose vials of drugs, the number of blood transfusions received and the length of time on hemodialysis play a role in such outbreaks ${ }^{(7)}$.

For many years, viral hepatitis was recognized as a hazard for hemodialysis patients and staff ${ }^{(17)}$. The term viral hepatitis can describe either a clinical illness or the histologic findings associated with the disease. It is most caused by the hepatitis A virus (HAV), hepatitis $\mathrm{B}$ virus (HBV), and hepatitis $\mathrm{C}$ virus (HCV). Also, there are many other hepatotropic viruses include hepatitis $\mathrm{D}$ virus (HDV) and hepatitis E virus (HEV). Infrequent causes of viral hepatitis include adenovirus, cytomegalovirus (CMV), Epstein-Barr virus (EBV), and rarely, herpes simplex virus (HSV) ${ }^{\left({ }^{8}\right)}$.

The hepatitis B virus (HBV) is a well-known blood-borne virus because it is transmitted through exposure to infective blood, semen, and other body 
fluids, peripheral blood mononuclear cells (PBMCs), and sharing needles ${ }^{(\mathbf{1}, \mathbf{9})}$.

Acute HBV can be a self-limiting or it can be a chronic infection and increases the risk of developing liver failure, Hepatocellular carcinoma (HCC), or cirrhosis ${ }^{(2)}$.

HBV infection is a major cause of chronic liver disease, affecting more than 240 million people worldwide ${ }^{(\mathbf{1 0}, 11)}$.

The diagnosis of acute HBV infection is based on the presence of $\mathrm{HBsAg}$, anti-HBc (IgM), and $\mathrm{HBeAg}$ in serum. HBV DNA is also detectable during acute and chronic infection. Chronic HBV infection is pinpointed by the presence of $\mathrm{HBs} \mathrm{Ag}$ in serum for at least six months. The meliorated carrier attitude is diagnosed by normal ALT levels, absence of $\mathrm{HBe} \mathrm{Ag}$, presence of anti-HBe, and undetectable or low levels of HBV DNA $(<200 \mathrm{UL} / \mathrm{mL})$. Active carrier state is determined by high viral load ( $\geq 20000 \mathrm{UI} / \mathrm{mL}$ ), whereas HBeAg could be present or absent with anti-HBe positivity ${ }^{(12)}$.

Occult hepatitis B infection (OHBI) is a new clinical form of hepatitis B that characterized as the presence of HBV DNA in the liver with detectable $(<200 \mathrm{UI} / \mathrm{mL})$ or undetectable HBV DNA in the serum in HBsAg negative patients and can be classified into seropositive (anti-HBc and/or anti-HBs positive) and seronegative (absence of anti-HBV and anti-HBs) ${ }^{(13)}$.

It is estimated that about $20 \%$ of OHBI infections are negative for all HBV serological markers but HBV DNA is detectable although the HBV viral load is may be often low. The seronegative OHBI pattern is very important as a source of infection but it is very difficult to diagnose due to the absence of serum HBV antigens or antibodies ${ }^{(\mathbf{4})}$.

In the diagnosis of OHBI, a liver biopsy may be needed. OHBI is one of the most common causes of liver diseases in negative HBsAg patients ${ }^{(\mathbf{1 4})}$.

The prevalence of OHBI varies from $1 \%$ to $87 \%$ in different regions of the world. The frequency of OHBI in patients with liver cirrhosis and cryptogenic chronic liver ranged from $2.7 \%$ to $60 \%$ and $1.9 \%$ to $55.6 \%$ respectively ${ }^{(4)}$.

Patients with chronic renal failure (CRF) on hemodialysis are at higher risk for acquiring Hepatitis B Virus ${ }^{(5)}$.

HD patients, compared to patients without renal failure are more to become chronic HBV carriers ${ }^{(\boldsymbol{(})}$.

Using common equipment for multiple blood transfusions, inadequate infection control methods, breaching of skin, and the suppressed immunity of CRF-HD patients leads to a high prevalence of OHBI rather than the general population ${ }^{(15)}$.

The prevalence of OHBI among hemodialysis patients and blood donors has been reported from $0 \%$ to $58 \%$ and 0 to $22.7 \%$ in different places of the world. Thus, the important measure should be implemented to control of hepatitis in all dialysis departments ${ }^{(\mathbf{1 6})}$.
The present study enrolled HBsAg negative patients, regardless of their HCV RNA status, demonstrated that $37.5 \%$ of patients with ESRF had OBI. Supporting our result, Abu El Makarem et al. ${ }^{(17)}$ found the prevalence of anti-HBc was 20\%. Abdelaziz et al. ${ }^{(18)}$ found the prevalence of anti-HBc was $35.5 \%$.

Previous reports from studies in dialysis units have indicated that the prevalence of OBI ranges from $0 \%$ to $58 \%$ among patients ${ }^{(19)}$. This wide range of estimates may attributable to differences in the sensitivity of the methods used for the detection of HBV DNA $^{(20)}$, the patients' sample investigated in each study and the level of HBV endemicity in the populations of the different geographic areas. The most accurate method for OBI testing is the analysis of liver DNA extracts and the detection of HBV DNA in serum samples may underestimate the true prevalence of OBI (19). However, the performance of liver biopsies in patients undergoing HD is often very difficult and is usually contraindicated. A similar prevalence of markers of anti-HBc and HBV DNA has recently been found among Egyptian blood donations ${ }^{(19)}$.

In a study by Gwak et al. ${ }^{(21)} 65.8 \%$ were anti$\mathrm{HBc}$ positive. In a study involving subjects from Turkey, occult hepatitis B infection was found in 2.7\% of HD patients ${ }^{(22)}$. In other studies, the prevalence of occult HBV reached in Spain 58\% ${ }^{(23)}$, Canada $3.8 \%{ }^{(24)}$, Italy $0 \%{ }^{(25)}$. Turkey $0 \%, 1.2 \%, 12.4 \%$ and $16.9 \%{ }^{(26)}$.

There is also in this study the significant positive correlation between the Anti-HBc level and duration of hemodialysis.

In agreement with our study Minuk et al. (24) found no significant relationship between age, sex, and anti-HBc positivity. In agreement with our study is Chemin and Zoulim ${ }^{(27)}$ found a significant correlation between anti $\mathrm{HCV}$ and anti-HBc positivity and also Bozza et al. ${ }^{(28)}$ found a significant relationship between anti HCV and anti-HBc positivity.

As they have similar transmission modes, HBV and $\mathrm{HCV}$ co-infection is common clinical presentations. Because prevention is the first line of defense against viral hepatitis infection and is much more cost-effective than treatment, prevention should be the main goal of current efforts to break the vicious cycle of the infection ${ }^{(17)}$.

On the contrary, a study by Abu El Makarem $\boldsymbol{e t}$ al. ${ }^{(17)}$ observed no significant association between anti$\mathrm{HCV}$ positivity and the prevalence of occult hepatitis B virus.

In agreement with our study, Abu El Makarem et al. ${ }^{(17)}$ found no significant association between HBV seropositivity and age, sex as well as liver enzymes.

In agreement with our study, Abdelaziz et al. ${ }^{(18)}$ found a significant association between HBV seropositivity and duration of hemodialysis, transfusion units of blood per month. 
On the contrary, a study by Abu El Makarem $\boldsymbol{e t}$ al. ${ }^{(17)}$ found no significant association between HBV seropositivity and duration of dialysis. They also observed that there is a significant association between the presence of HBV DNA and anti-HBc positivity.

\section{CONCLUSION}

OBI infection is a relatively common infection (37.5\%) among chronic hemodialysis patients in the dialysis unit of Fakous general hospital. OBI might be another example of a highly successful and widely distributed virus capable of establishing a commensal relationship with its host and may play a role in maintaining homeostasis.

\section{REFERENCES}

1. Rastegarvand N, Makvandi M, Samarbafzadeh A et al. (2015): Molecular characterization of pre-core/core and $s$ region of hepatitis $b$ virus in hemodialysis patients with occult hepatitis $b$ infection. Jundishapur $\mathbf{J}$ Microbiol., 8:1-5

2. Sundaram V, Kowdley K (2015): Management of chronic hepatitis b infection. Br Med J., 5: 1-12.

3. Schaefer S (2007): Hepatitis B, virus taxonomy, and hepatitis B virus genotypes. World J Gastroenterol., 13:14-21.

4. Makvandi M (2016): Update on occult hepatitis b virus infection. World J Gastroenterol., 22:8720-34.

5. Esmat M, Mohamed T, Zazi N (2015): Occult Hepatitis b virus infection among Egyptian hepatitis c virus seropositive and seronegative hemodialysis patients in Sohag government, Upper Egypt. Egypt J Med Microbiol., 24:113-8

6. Saijo T, Joki N, Inishi Y et al. (2015): Occult hepatitis $\mathrm{b}$ virus infection in hemodialysis patients in Japan. Ther Apher Dial., 19:125-30.

7. Alter M, Margolis H (1990): The emergence of hepatitis B as a sexually transmitted disease. Med Clin North Am., 74:1529-1541.

8. 18-Wasley A, Kruszon-Moran D, Kuhnert W et al. (2010): The prevalence of hepatitis B virus infection in the United States in the era of vaccination. J Infect Dis., 202:192-201.

9. Hornor G (2017): Sexually transmitted infections and children: what the PNP should know. J Pediatr Health Care, 31:222-9.

10. Meidani M, Rostami M, Hemmati S et al. (2016): Screening and evaluation of chronic and occult Hepatitis $b$ in chemoradiotherapy patients with cancer. Adv Biomed Res., 5:85-92.

11. Rosa A, Araujo O, Savassi-Ribas F et al. (2017): Prevalence of occult hepatitis B virus infection and their association with hepatocellular carcinoma in chronic hepatitis c patients. Virus Res., 242:166-72.

12. -Kwo P, Cohen S, Lim J (2017): ACG clinical guideline: evaluation of abnormal liver chemistries. Am J Gastroenterol., 112:8-35.
13. Saha D, Pal A, Sarkar N et al. (2017): Occult hepatitis b virus infection in HIV positive patients at a tertiary healthcare unit in eastern India. PloS One, 12:1-18.

14. Nishikawa H, Osaki Y (2013): Clinical significance of occult hepatitis $b$ infection in the progression of liver disease and carcinogenesis. J Cancer, 4:473-80.

15. Sumida Y, Nakajima A, Itoh Y (2014): Limitations of liver biopsy and non-invasive diagnostic tests for the diagnosis of nonalcoholic fatty liver disease/nonalcoholic steatohepatitis. World J Gastroenterol., 20:475-85.

16. Ayatollahi J, Jahanabadi S, Sharifyazdi $M$ et al. (2017): The Prevalence of occult Hepatitis b virus in the hemodialysis patients in Yazd, Iran. Acta Med Iran, 54:784-7.

17. Abu El Makarem M, Abdel Hamid M, Abdel Aleem A et al. (2012): Prevalence of occult hepatitis B virus infection in hemodialysis patients from Egypt with or without hepatitis $\mathrm{C}$ virus infection. Hepat Mon., 12:253-258.

18. Abdelaziz N, Fekry M, Hashish M (2019): Occult Hepatitis B Virus Infection in Egyptian HIV-infected Patients with Isolated Anti-HBc. Journal of High Institute of Public Health, 49(3):162-167.

19. Raimondo G, Pollicino T, Cacciola I et al. (2007): Occult hepatitis B virus infection. J Hepatol., 46(1):160-70.

20. Siagris D, Christofidou M, Triga K (2006): Occult hepatitis B virus infection in hemodialysis patients with chronic HCV infection. J Nephrol., 19(3):327-33.

21. Gwak G, Huh W, Lee D et al. (2008): Occult hepatitis $B$ virus infection in chronic hemodialysis patients in Korea Hepatogastroenterology, 55 (86-87):1721-4.

22. Yakaryilmaz F, Gurbuz O, Guliter S et al. (2006): Prevalence of occult hepatitis B and hepatitis $\mathrm{C}$ virus infections in Turkish hemodialysis patients. Ren Fail., 28(8):729-35.

23. Cabrerizo M, Bartolome J, Caramelo C et al. (2000): Molecular analysis of hepatitis B virus DNA in serum and peripheral blood mononuclear cells from hepatitis B surface antigen-negative cases. Hepatology, 32(1):116-23.

24. Minuk G, Sun D, Greenberg $R$ et al. (2004): Occult hepatitis $\mathrm{B}$ virus infection in a North American adult hemodialysis patient population. Hepatology, 40 (5):1072-7.

25. Fabrizi F, Messa P, Lunghi G et al. (2005): Occult hepatitis $\mathrm{B}$ virus infection in dialysis patients: a multicentre survey. Aliment Pharmacol Ther., 21(11):1341-7.

26. Goral V, Ozkul H, Tekes S et al. (2006): Prevalence of occult $\mathrm{HBV}$ infection in hemodialysis patients with chronic HCV. World J Gastroenterol., 12(21):3420-4.

27. Chemin I, Zoulim F (2009): Hepatitis B virus-induced hepatocellular carcinoma. Cancer Lett., 286:52-9.

28. Bozza C, Cinausero M, Iacono D et al. (2016): Hepatitis b and cancer: a practical guide for the oncologist. Crit Rev Oncol Hematol., 98:137-46. 